\title{
Die definiëring van persoonlike besparing: Die Suid-Afrikaanse situasie 1965.1 tot 1984.4
}

\author{
P. Styger* en J.H.P. van Heerden \\ Departement Ekonomie en Geld-en Bankwese, PU vir CHO, Potchefstroom 2520 \\ Republiek van Suid-Afrika
}

\begin{abstract}
The definition of personal savings: The South African situation 1965.1 to 1984.4. The personal savings definition, and through that also the time series of personal savings in South Arrica in common use, can be described as personal savings as published, amongst others, by the South African Reserve Bank. In the computation of the above time series there are certain deficiencies and the time series has been queried since the sixties. The objective of this study was to undertake an empirical study of the definition of personal savings in South Africa and through that also the time series of personal savings, and possibly to improve on these. It was indicated that the published personal savings cannot be regarded as a good definition of personal savings in South Africa. Various altemative personal savings definitions were studied critically and it was indicated that it would seem that long-term insurance premiums plus pension fund contributions (i.e. contractual personal savings) should constitute the personal savings definition for South Africa.
\end{abstract}

Die persoonlike besparingsdefinisie en daardeur ook die tydreeks van persoonlike besparing in Suid-Afrika, wat algemeen gebruik word, is die gepubliseerde persoonlike besparing, soos onder andere deur die SuidAfrikaanse Reserwebank gepubliseer. In die berekening van bogenoemde tydreeks is daar sekere leemtes en die tydreeks word sedert die sestigerjare bevraagteken. Die doel van hierdie studie was om die definiëring van persoonlike besparing in Suid-Afrika en daardeur ook die tydreeks van persoonlike besparing empiries te ondersoek en moontlik te verbeter. Daar is aangetoon dat die gepubliseerde persoonlike besparing nie as 'n goeie definisie van persoonlike besparing vir Suid-Afrika beskou kan word nie. Verskeie altematiewe persoonlike besparingsdefinisies is krities ondersoek en daar is aangetoon dat langtemynversekeringspremies plus pensioenfondsbydraes (m.a.w. kontraktuele persoonlike besparing) die persoonlike besparingsdefinisle vir Suid-Afrika kan wees.

Hierdie artikel is 'n kort opsomming van die belangrikste bevindings in 'n ongepubliseerde DComm.-prockskif deur $P$. Styger

*Aan wie korrespondensie gerig moet word

\section{Inleiding en motivering}

Die persoonlike besparingsdefinisie en daardeur ook die tydreeks van persoonlike besparing in Suid-Afrika, wat algemeen gebruik word, is die gepubliseerde persoonlike besparing soos onder andere deur die Suid-Afrikaanse Reserwebank in sy Kwartaalblad gepubliseer. Die doel van hierdie studie is om die definiëring van persoonlike besparing in Suid-Afrika en daardeur ook die tydreeks van persoonlike besparing, empiries te ondersoek.

Die noodsaaklikheid van investering om aan die demografiese, sosiale, politiese en ekonomiese eise van Suid-Afrika te kan voldoen is algemeen bekend. Die beperkings wat op investering deur die onvoldoende finansieringsbronne in Suid-Afrika geplaas word, is goed bekend. Waar Suid-Afrika in die verlede op 'n invloei van buitelandse fondse, om die tekorte in die bruto binnelandse besparing aan te vul, kon staatmaak, het die toenemende druk op Suid-Afrika onder andere as gevolg van die disinvesteringsveldtog en die skuldstistandsooreenkoms, die situasie aansienlik laat versleg. Die toekomstige groei in die kapitaalvoorraad via investering, sal in 'n al groter mate van die vlak van bruto binnelandse besparing afhang.

In hierdie studie is op net een komponent van bruto binnelandse besparing, naamlik persoonlike besparing, gekonsentreer. Die klem val op persoonlike besparing as gevolg van die belangrike rol wat dit in die toekoms, as finansieringsbron van investering, sal moet speel. Die rede vir die klem op persoonlike besparing en nie op owerheids- of maatskappybesparing nie, is dat owerheidsbesparing hoofsaaklik 'n teoretiese begrip is omdat dit ontstaan wanneer die lopende besteding van die owerheid in ' $n$ betrokke kwartaal minder as die lopende inkomste in daardie kwartaal is. Daar kan nie op hierdie lopende surplusse vir investering gesteun word nie. As gevolg van onder andere buitelandse druk en die volgehoue inflasieprobleem het die mededingendheid en winsgewendheid van die Suid-Afrikaanse nywerheidsen sakesektor verminder en gevolglik maatskappybesparing laat afneem. Dit is derhalwe noodsaaklik om te weet wat persoonlike besparing presies is, sodat dit aangemoedig kan word. Dit moet ook vasgestel word watter persoonlike inkome-komponent finansier die betrokke persoonlike besparing.

\section{Persoonlike besparingsfunksies}

Die eerste stap in die proses om persoonlike besparing te definieër was die identifisering van persoonlike besparingsfunksies. Agtien persoonlike besparingsfunksies is met behulp van 'n literatuursoektog identifiseer. Sommige van die persoonlike besparingsfunksies was oorspronklik in die literatuur as verbruiksfunksies voorgehou. Uit die breë verwantskap tussen inkome, verbruik en besparing, naamlik dat besparing die deel van 'n verbruiker se inkome is wat oorbly nadat hy verbruik het, kan geargumenteer word dat die faktore wat verbruik beinvloed, ook persoonlike besparing beinvloed, maar net in die omgekeerde rigting. Die funksies wat persoonlike verbruik beskryf kan daarom ook 
gebruik word om persoonlike besparing te beskryf.

Die funksies wat geidentifiseer is, beskryf persoonlike besparing en/of verbruik en die determinante daarvan in die buiteland en ten opsigte van verbruik ook in SuidAfrika (kyk Van Zyl, 1970; Stuart, 1979). Daarom behoort die tydreekse van persoonlike besparing of 'n komponent van persoonlike besparing wat die beste resultate met hierdie funksies lewer, dié definisie van persoonlike besparing vir Suid-Afrika te wees. Die verskillende persoonlike besparingsfunksies verskyn in Tabel 1.

\section{Verskillende persoonllke besparingsdefinisies}

In hierdie afdeling sal daar telkens 'n kort beskrywing van elke tydreeks van persoonlike besparing wees sowel as die beste resultate wat behaal is deur die funksies van Tabel 1 op dié tydreeks te pas. Die tydreeks van persoonlike besparing wat die beste resultate (in terme van $\bar{R}^{2}$ en C.V.) lewer is die definisie wat persoonlike besparing in Suid-Afrika die beste beskryf.

\section{Gepubliseerde persoonlike besparing}

Gepubliseerde persoonlike besparing is die residu van die berekeningsproses van die kapitaalfinansieringsrekening van die Nasionale Rekeninge. Bo en behalwe die feit dat van steekproewe, sensusse en ramings in bogenoemde berekeningsproses gebruik gemaak word, stel Stadler (1973: 160) dit dat alle foute en weglatings in die berekeningsproses na persoonlike besparing oorgedra word. Die gepubliseerde persoonlike besparingstydreeks kan dus aan aansienlike foutvariansie onderhewig wees.

Die beste resultate met hierdie definisie van persoonlike besparing is met die funksie van Tobin (1952) en Zellner (1957) behaal met $\overline{\mathrm{R}}^{2}=0,7004$ en C.V. $=62,34$. In die lig van onder andere die studie van Craig (1970: 1135), Howard (1978: 530) en Peasaran en Evans (1984: 252) se resultate $\left(\overline{R^{2}}=0,99\right.$ en $\overline{R^{2}}=0,97$ en C.V. $=5,4$ en C.V. $=5,3)$ met tydreekse van onder andere die V.S.A., Kanada, Duitsland, Japan en Groot Brittanje, kan dit op grond van die hoë C.V.-waarde vir SuidAfrika gestel word dat gepubliseerde persoonlike besparing nie 'n goeie definisie vir persoonlike besparing in Suid-Afrika is nie.

Alternatiewe vloeibenadering om persoonlike besparing te bereken

Per definisie is persoonlike besparing die verskil tussen persoonlike beskikbare inkome en totale persoonlike verbruiksbesteding. Die definisie kan as 'n alternatiewe metode om persoonlike besparing te bereken, gebruik word. Net soos by die gepubliseerde persoonlike besparing is hierdie definisie ook 'n residu van berekeningsproses. In hierdie geval is dit die residu van die verskil tussen twee tydreekse wat uit groot getalle bestaan. ' $n$ Klein foutgrens in die data kan tot groot afwykings in die persoonlike besparingstydreeks lei.

Die beste resultate met die definisie is met die funksie van Tobin en Zellner behaal met C.V. $=26,76$ en $\overline{\mathbf{R}^{2}}=$ 0,8531. As gevolg van die hoé C.V.-waarde kan dit
Tabel 1 Verskillende persoonlike besparingsfunksies

\begin{tabular}{|c|c|}
\hline Skrywer & Funksie \\
\hline Keynes & $S_{1}=\alpha+\beta_{1} Y_{t}$ \\
\hline Mack & $S_{t}=\alpha+\beta_{1} Y_{t}+\beta_{2} \Delta Y_{t}$ \\
\hline Friedman & $S_{t}=\alpha+\beta_{1} Y_{1}+\beta_{2} C_{1}+\beta_{3} L_{1-1}$ \\
\hline $\begin{array}{l}\text { Tobin; } \\
\text { Zellner }\end{array}$ & $S_{1}=\alpha+\beta_{1} Y_{t}+\beta_{2} C_{1-1}+\beta_{3} L_{1-1}$ \\
\hline $\begin{array}{l}\text { Ando \& } \\
\text { Modigliani }\end{array}$ & $\begin{array}{l}S_{t}=\alpha+\beta_{1} Y_{t}+\beta_{2} Y_{t}+\beta_{3} A_{t-1} \\
S_{t}=\alpha+\beta_{1} Y_{t}+\beta_{2}\left(N_{\sqrt{2}} E_{t}\right) Y_{t}+\beta_{3} A_{t-1}\end{array}$ \\
\hline $\begin{array}{l}\text { Houthakker } \\
\text { \& Taylor }\end{array}$ & 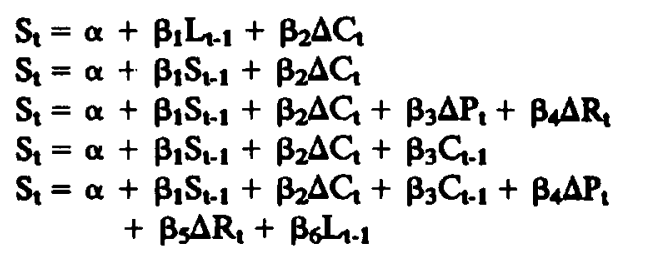 \\
\hline $\begin{array}{l}\text { Friend \& } \\
\text { Taubman }\end{array}$ & $S_{1}=\alpha+\beta_{1} Y_{1}+\beta_{2} X_{1}+\beta_{3} Z_{2}$ \\
\hline $\begin{array}{l}\text { Burch \& } \\
\text { Werneke }\end{array}$ & $S_{t}=\alpha+\beta_{1} C_{t-1}+\beta_{2} \Delta Y_{1}+\sum_{1}^{4} \beta_{3} L_{t-1}+\beta_{4} \Delta P_{t}$ \\
\hline $\begin{array}{l}\text { Somermeyer } \\
\text { \& Bannink }\end{array}$ & $S_{t}=\alpha+\beta_{1} R^{\prime}+\beta_{2} K_{t}$ \\
\hline Howard & $\begin{aligned} S_{1}=\alpha & +\beta_{1} Y_{1}+\beta_{2} Y T_{t}+\beta_{3} L_{t-1}+\beta_{4} R_{t} \\
& +\beta_{5} P_{t}+\beta_{6} P_{t}^{*}+\beta_{7} W_{t}+\beta_{8} \Delta W_{t}\end{aligned}$ \\
\hline $\begin{array}{l}\text { Deaton; } \\
\text { Fortune }\end{array}$ & $\begin{array}{l}\Delta_{h}(S / Y)_{t}=\alpha+\beta_{1} \Delta Y_{t}+\beta_{2} \Delta P_{t}+\beta_{3}(S / Y)_{t-h} \\
\Delta_{h}(S / Y)_{t}=\alpha+\beta_{1} \Delta Y_{t}+\beta_{2} P_{t}+\beta_{3}(S / Y)_{t h}\end{array}$ \\
\hline Stuart & $\begin{aligned} S_{1}=\alpha & +\beta_{1} Y V_{1}+\beta_{2} Y_{t}+\beta_{3} F_{t}+\beta_{4} T_{t} \\
& +\beta_{5} W_{t}+\beta_{6} R_{t}\end{aligned}$ \\
\hline
\end{tabular}

gestel word dat die alternatiewe vloeimetode nie 'n goeie definisie vir persoonlike besparing in Suid-Afrika is nie. 
Persoonlike deposito's by die bankinstellings

Die bankinstellings (handelsbanke, aksepbanke, monetêre bankinstelling en ander Suid-Afrikaanse bankinstelling) se tydreekse is verkry uit die kwartaalopgawes wat deur die bankinstellings, in terme van die Bankwet van 1965 (Staatskoerant, 1978) aan die Registrateur van Finansiële Instellings en die Reserwebank verskaf moes word. Die data word op die sogenaamde 'BW-Vorm 9' verskaf wat 'n gedetailleerde opgawe van die bankinstellings se bates en laste vir 'n betrokke kwartaal is. Ongelukkig word die deposito's wat deur individue by die bankinstellings gehou word, nie as 'n aparte item op die BW-Vorm 9 vereis nie. Die gegewens wat vir die doeleindes van hierdie studie gebruik is, is onttrek uit die lastestaat van die BW-Vorm 9 (Staatskoerant, 1978: 10). Subpos (xiv) van die BW-Vorm 9 is die beste benadering van die banke se verpligtings teenoor individue. Die tydreekse word nie deur die Reserwebank gepubliseer nie en is met die hulp van hul Ekonomieseafdeling opgestel.

Alhoewel individue baie selde deposito's by aksepbanke hou (Falkena, Fourie en Kok, 1984: 74-82) is die data van aksepbanke wel in die studie ingesluit. Die rede vir die insluiting lê daarin dat persoonlike beskikbare inkome die pos 'inkome uit eiendom van huishoudings' insluit. Inkome uit eiendom van huishoudings sluit onder andere die winste van nie-geïnkorporeerde sakeondernemings in. Nie-geïnkorporeerde sakeondernemings hou wel deposito's by aksepbanke. Daar is ook tydreekse saamgestel waar die deposito's van aksepbanke uitgesluit is vir gebruik saam met die inkomebegrip 'vergoeding van werknemers' wat nie die inkome van ondernemings insluit nie. Samevattend kan dit gestel word dat daar twee 'hoof'-groepe tydreekse saamgestel is, naamlik een groep waarby die persoonlike deposito's by aksepbanke ingesluit is vir gebruik saam met die inkomebegrippe 'persoonlike beskikbare inkome' en 'inkome uit eiendom van huishoudings' en 'n ander groep tydreekse sonder die deposito's by aksepbanke vir gebruik saam met die inkomebegrip 'vergoeding van werknemers'. Die tydreekse is onmiddellike opeisbare deposito's, korttermyndeposito's (onmiddellike opeisbare deposito's uitgesluit), spaardeposito's, middeltermyndeposito's (spaardeposito's uitgesluit) en langtermyndeposito's.

Net die heel beste resultaat wat behaal is, deur die funksies van Tabel 1 op bogenoemde tydreekse te pas, word gerapporteer. Die beste resultaat is met persoonlike onmiddellike opeisbare deposito's by die bankinstellings, aksepbanke ingesluit, as persoonlike besparingsdefinisie en met inkome uit eiendom van huishoudings as inkomedefinisie en die funksie van Burch en Werneke (1975) verkry. Die resultate is $\overline{R^{2}}=0,5370$ en C.V. $=98,32$. Gegewe die lae $\bar{R}^{2}$ en hoë C.V.-waarde en die feit dat al die ander resultate swakker was, kan dit gestel word dat persoonlike deposito's by die bankinstelling, binne die konteks van hierdie studie, nie 'n goeie definisie vir persoonlike besparing in Suid-Afrika opgelewer het nie.

\section{Deposito's by die Posspaarbank}

By die Posspaarbank mag net individue deposito's hou. Die tydreekse van die Posspaarbank is dus 'beter' as die van die bankinstellings wat ook deposito's van ander instellings insluit. Drie tydreekse, naamlik spaarrekenings, spaarbanksertifikate en nasionale spaarsertifikate is deur die Posspaarbank beskikbaar gestel. Omdat slegs individue deposito's by die Posspaarbank hou, is net 'vergoeding van werknemers' as inkomedefinisie gebruik.

Die beste resultate is met die funksie van Howard en spaarrekenings by die Posspaarbank as persoonlike besparingsdefinisie behaal. Dié resultate is $\overline{\mathrm{R}}^{2}=0,8363$ en C.V. $=-85,44$. Gegewe die hoë C.V.-waarde kan dit gestel word dat die deposito's by die Posspaarbank, binne die konteks van hierdie studie, nie 'n goeie definisie vir persoonlike besparing in Suid-Afrika oplewer nie.

\section{Deposito's by die bougenootskappe}

'n Instelling wat oor akkurate syfers van bouverenigings se deposito's en aandele beskik, het die tydreekse op kwartaalbasis slegs vir navorsingsdoeleindes beskikbaar gestel omdat dit van bougenootskappe net vereis word om jaarliks gedetailleerde verslae aan die Registrateur te verskaf. Die volgende tydreekse is saamgestel: gewone spaarrekenings, spesiale spaarrekenings, vaste deposito's, belastingvrye opbetaalde aandele, vaste periode aandele (gedeeltelik belastingvry) en totale deposito's plus aandele. Vergoeding van werknemers is weer as die persoonlike inkomedefinisie geneem.

Die beste resultate is met die funksie van Stuart met belastingvrye opbetaalde aandele as persoonlike besparingsdefinisie en vergoeding van werknemers as persoonlike inkomedefinisie behaal. Die resultate is $\frac{\mathbf{R}^{2}}{=}$ 0,3961 en C.V. $=-165,43$. Gegewe die lae $\bar{R}^{2}$ - en hot C.V.-waarde kan dit gestel word dat die deposito's by bougenootskappe, binne die konteks van hierdie studie, nie 'n goeie definisie vir persoonlike besparing in SuidAfrika oplewer nie.

\section{Langtermynversekering en pensioenfondse}

Al die voorgaande deposito's is vorme van diskresionere persoonlike besparing. In hierdie afdeling word kontraktuele persoonlike besparing ondersoek. Die tydreeks vir langtermynversekeringpremies is met die hulp van die Reserwebank opgestel. Die tydreeks vir pensioenfondsbydraes (pensioenfondse plus voorsorgfondse plus onderlinge hulpverenigings) is ook met die hulp van die Reserwebank opgestel en bevat die data ten opsigte van ledebydraes tot private en staatsbeheerde pensioenfondse. Beide die langtermynversekeringspremies en pensioenfondsbydraes is slegs dié deel wat die individue self uit hul vergoeding betaal en sluit nie die deel wat die werkgewers, as deel van die diensvoorwaardes oorbetaal, in nie. Die inkomedefinisie is weer vergoeding van werknemers.

Die beste resultate met langtermynversekeringspremies as persoonlike besparingsdefinisie is met die funksie van Howard behaal en is soos volg: $\overline{R^{2}}=$ 
0,9647 en C.V. $=4,31$. Die beste resultate met pensioenfondsbydraes as persoonlike besparingsdefinisie is ook met die funksie van Howard behaal en is soos volg: $\bar{R}^{2}=0,9410$ en C.V. $=4,28$.

As bogenoemde twee reekse tot een reeks saamgestel word, word die beste resultate van die studie met die funksie van Howard verkry. Die volledige resultate is soos volg:

$$
\begin{aligned}
& S_{t}=350,260-0,079 Y_{t}+0,389 Y T_{t}-0,0167 L_{t-1} \\
& (-0,702) \quad(2,414) * \quad(-0,625) \\
& +0,848 R_{t}-2,301 P_{t}+4,719 P * t-0,976 W_{t} \\
& (0,397) \quad(-0,905) \quad(1,706)^{*} \quad(-0,426) \\
& 0,356 \mathrm{~W}_{\mathrm{t}} \\
& (0,107)
\end{aligned}
$$

$\overline{\mathbf{R}^{2}}=0,9695$

C. V. $=3,87$

D.W. $=2,414$

In die lig van bogenoemde resultate kan dit gestel word dat kontraktuele besparing (langtermynversekeringspremies, plus pensioenfondsbydraes) die definisic van persoonlike besparing in Suid-Afrika kan wees. Net twee koëffisiënte van die funksie wat hierbo gerapporteer is, verskil op 'n $10 \%$-peil van betekenis, betekenisvol van nul. Die koëffisiënte van tydelike inkome $\left(\mathrm{YT}_{t}\right)$ en verwagte inflasie $\left(\mathrm{P}^{*}\right)$ verskil betekenisvol van nul. Dit wil voorkom of kontraktuele persoonlike besparing in Suid-Afrika, oor die periode van die studie, hoofsaaklik as verskansing teen inflasie gedien het. Die feit dat kontraktuele persoonlike besparing uit die tydelike en nie uit permanente inkome gefinansier word, sal eers indringend nagevors moet word voordat 'n uitspraak oor die redes vir dié verskynsel gelewer word.

Naby-substitute vir die 'eng' persoonlike besparingsdefinisie in die investeringsproses

In die vorige afdeling is bevind dat langtermynversekeringspremies plus pensioenfondsbydraes die definisie van persoonlike besparing in Suid-Afrika kan wees. Die vraag ontstaan egter of dié definisie van persoonlike besparing nie te 'eng' is en of dié definisie nie verder uitgebrei kan word nie.

Daar is met behulp van die FriedmanMeiselmantegniek (Friedman \& Meiselman, 1963: 181) en die gewysigde Friedman-Meiselmantegniek (Van Heerden, 1980: 21 - 52) getoets of een of meer van al die persoonlike besparingsdefinisies wat ter sprake was, nie dalk naby-substitute van kontraktuele persoonlike besparing (pensioenfondsbydraes plus langtermynversekeringspremies) in die Suid-Afrikaanse investeringsproses is nie. Indien daar wel sulke nabysubstitute gevind kon word, kon die 'eng' definisie daarmee uitgebrei word.
Op 'n 5\%-peil van betekenis kon daar nie 'n nabysubstituut vir pensioenfondsbydraes plus langtermynversekeringspremies in die Suid-Afrikaanse investeringsproses geïdentifiseer word nie. Die bevinding dat pensioenfondsbydraes plus langtermynversekeringspremies die definisie vir persoonlike besparing in Suid-Afrika is, word bevestig.

\section{Samevatting}

Die doel van hierdie studie was om die persoonlike besparingsdefinisie en daardeur die tydreeks van persoonlike besparing in Suid-Afrika krities te ondersoek. Daar is aangetoon dat die persoonlike besparingsdefinisie wat algemeen in Suid-Afrika gebruik word, naamlik gepubliseerde persoonlike besparing, nie as 'n goeie definisie vir persoonlike besparing in SuidAfrika beskou kan word nie. Verskeie alternatiewe definisies van persoonlike besparing in Suid-Afrika is oorweeg. Ook hierdie definisies is krities ondersoek en daar is aangetoon dat dit blyk dat pensioenfondsbydraes plus langtermynversekeringspremies die persoonlike besparingsdefinisie vir Suid-Afrika behoort te wees.

Daar is verder aangetoon dat daar nie nabysubstitute vir bogenoemde persoonlike besparingsdefinisie in die Suid-Afrikaanse investeringsproses is nie. Daar word derhalwe met die definisie van persoonlike besparing as synde kontraktuele persoonlike besparing (pensioenfondsbydraes plus langtermynversekeringspremies) volstaan.

'n Verdere bevinding is dat die persoonlike inkomebegrip (of inkomedefinisie) waaruit kontraktuele persoonlike besparing onderneem word, vergoeding van werknemers is wat 'n komponent van persoonlike beskikbare inkome is. Persoonlike beskikbare inkome is tradisioneel met persoonlike besparing geidentifiseer.

Daar is ook aangetoon dat kontraktuele persoonlike besparing oor die periode van die studie, hoofsaaklik as verskansing teen verwagte inflasie gedien het. Die feit dat kontraktuele persoonlike besparing uit die tydelike inkomekomponent gefinansier word, impliseer dat die gesonde praktyk, van eers spaar en dan koop, nie in Suid-Afrika nagevolg word nie. Hierdie afleiding moet beoordeel word teen die feit dat die diskresionêre besparing in ander lande deur die tydelike inkomekomponent gefinansier word.

Die feit dat die nuwe persoonlike besparingsdefinisie so 'n 'eng' definisie is, die feit dat daar nie nabysubstitute vir die 'eng' definisie in die Suid-Afrikaanse investeringsproses gevind kon word nie en die langtermyn aard van persoonlike besparing, kan as redes aangevoer word waarom die huidige stappe om persoonlike besparing, in die breè, aan te moedig nie suksesvol sal wees nie. Dit kom daarop neer dat die verkeerde groothede in die verlede aangemoedig is. Daar sal daadwerklike pogings van die finansiële instellings en die owerheid moet kom om vas te stel waarom die definisie van persoonlike besparing in die praktyk so 'eng' geword het.

Vanweě die belangrike rol van die pensioenfondse en langtermynversekeraars in die investeringsproses, behoort hulle belastingposisie met baie groot omsigtigheid 
hanteer te word. Daar behoort indringend na moontlike doeltreffende maatreëls om persoonlike besparing, in die breë, aan te moedig gekyk te word.

\section{Summary}

The personal savings definition and through that also the time series of personal savings in South Africa in common use can be described as personal savings as published, amongst others, by the South African Reserve Bank. In the computation of the above time series there are certain deficiencies and the time series has been queried since the sixties (Ravenscroft, 1967). The objective of this study was to undertake an empirical study of the definition of personal savings in South Africa and through that also the time series of personal savings, and possibly to improve on these.

Some of the various theories on personal savings, or theories that could be applied to personal savings, were described. In the process eighteen different personal savings functions which suffice to describe personal savings overseas were illuminated. Following that the time series of the explanatory variables of the above eighteen personal savings functions were discussed. Alternative definitions for personal savings, as dependent variable, were investigated. These include, inter alia, the different personal deposits at banks, building societies and the Post Office Savings Bank as well as long-term insurance premiums and pension funds.

The various personal savings definitions for personal savings in South Africa were then studied with the aid of the above eighteen personal savings functions. It was indicated that the personal savings definition at present in general use in South Africa, namely, published personal savings, cannot be regarded as a good definition of personal savings in South Africa. The various alternative definitions were studied critically and it was indicated that it would seem that long-term insurance premiums plus pension fund contributions, within the context of this study, should constitute the personal savings definition for South Africa.

It was also indicated that there are no near-substitutes for long-term insurance premiums plus pension fund contributions in the South African process of investment.

A further finding has been that the personal income concept, from which the above personal savings are undertaken, rests on remuneration to employees. Remuneration of employees is a narrower definition of personal income than personal available income, which up to now has been used generally in South Africa as the concept of personal income. Personal available income has traditionally been identified with personal savings.

It was also indicated that it would seem that the newly-defined personal savings, for the period of the study, are used mainly as a hedge against inflation. The fact that pension fund contributions plus long-term insurance premiums are financed from the temporary income component possibly indicates that personal savings in South Africa have an essentially long-term character.

It is also averred that the 'narrow' definition of personal savings in South Africa and the long-term nature of personal savings should be seen as important reasons why the present steps to encourage personal savings in the wider context have not been successful.

It has been stated that if it were expected of the consumers to attach a significant savings character to the savings deposits of South African banking institutions, penetrating research would have to be done on the reasons why this is not happening. Real efforts will have to come from financial institutions and government to determine why the definition of personal savings in South Africa is so narrow in practice.

\section{Verwysings}

Ando A. \& Modigliani F. 1963. The 'life-cycle' hypotheses of saving: aggregate implications and tests. Am. Econ. Rev., vol. 53: 55-84.

Burch S. \& Werneke D. 1975. The stock of consumer durables, inflation and personal saving decisions. $R$ ev. Econ. Stat., vol.57: 141-154.

Craig G. 1970. Predictive accuracy of quarterly and annual aggregate saving functions. J. Am. Stat. Assoc., vol.65: $1131-1145$.

Deaton A. 1977. Involuntary saving through unanticipated inflation. Am. Econ. Rev., vol.67: 899-910.

Falkena H.B., Fourie L.J. \& Kok W.J. 1984. The mechanics of the South African financial system. Pretoria: Van Schaik.

Fortune N. 1981. Voluntary (dis)saving and expected inflation. South. Econ. J., vol.48: 134-143.

Friedman M. 1957. A theory of the consumption function. Princeton: Princeton University Press.

Friedman M. \& Meiselman D. 1963. The relative stability of monetary volocity and the investment multiplier. In Fox $B$. (ed.) Stabilization policies. New Yersey: Prentice Hall. 165- 268 .

Friend I. \& Taubman P. 1966. The aggregate propensity to save: some concepts and their applications in international data. Rev. Econ. Stat., vol.48: 113-123.

Houthakker H.S. \& Taylor L.D. 1970. Consumer demand in the United States, 1929-1970: analysis and projections. Cambridge: Harvard University Press.

Howard D.H. 1978. Personal savings behaviour and the rate of inflation. Rev. Econ. Stat., vol.60: 547-554.

Keynes J.M. 1942. The general theory of employment interest and money. London: Macmillan.

Mack R. 1948. The direction of change in income and the consumption function. Rev. Econ. Stat., vol.30: 239-258.

Peasaran M.H. \& Evans R.A. 1984. Inflation, capital gains and U.K. personal savings: 1953-1981. Econ. J., vol.94: 237-257.

Ravenscroft A.P. 1967. Personal sector of the Republic of South Africa income, saving and balance sheet, 1964. Voorlegging van die Buro van Statistiek aan die Suid-Afrikaanse Reserwebank.

Somermeyer W.H. \& Bannink R.A. 1972. Consumption-savings model and its applications. Amsterdam: North-Holland. 
Staatskoerant. Die Staatskoerant van die Republiek van Suid-Afrika.

26.2.1962, nr. 162 ,

27.8.1965. nr. 1212.

23.2.1968. nr. 1909 .

2.11.1973. nr. 4068 .

25.5.1977. nr. 5549 .

15.9.1978, nr. 6155.

19.5 .1980$, nr. 7029.

Stadler J.J. 1973. Die nasionale rekeninge van Suid-Afrika. Kaapstad: HAUM.

Stuart O.D.J. 1979. Verbruikersfunksies en hulle aanwending in Suid-Afrika vir vooruitskattingsdoeleindes. Proefskrif DComm.. Universiteit van Stellenbosch.
Suid-Afrikaanse Reserwebank. Kwartaalblad: 1966.1 tot 1985.3.

Tobin J. 1952. Asset holdings and spending decisions. Am. Econ. Rev., vol.42: 109-123.

Van Heerden J.H.P. 1980. Die identifisering van geldsubstitute met spesiale verwysing na die Suid-Afrikaanse situasie vir die periode 1965 tot 1979. Proefskrif DComm., PU vir C.H.O.

Van Zyl J.C. 1970. An econometric analysis of the consumption function in South Africa. Proefskrif DComm., Universiteit van Pretoria.

Zellner A. 1957. The short-run consumption function. Econometrica, vol.25: 552-566. 